\title{
Ірина Батюк
}

Національний педагогічний університет імені М. П. Драгоманова аспірантка (Україна) e-mail: irynabatiuk@ukr.net

ORCID: https://orcid.org/0000-0003-2381-3269

ResearcherID: https://publons.com/researcher/4274574/iryna-batiuk

\section{Масова безпритульність дітей України в роки Голодомору-геноциду 1932-1933 рр.}

Анотація. Mema cmammi. На основі комплексного аналізу архівних джерел, опублікованих документів і матеріалів, а також сучасних досліджень істориків, висвітлити явище масової дитячої безпритульності в Україні в роки Голодомору-геноциду, організованого російським комуністичним режимом у 1932-1933 роках. Проаналізувати діяльність органів держаної влади та створених ними комісій у наданні допомоги безпритульним дітям і подоланні цього трагічного соціального явища. Методологія дослідження грунтується на поєднанні загальнонаукових (аналізу і синтезу), спеціальноісторичних (проблемно-хронологічного, історико-системного) методів та принципів науковості й історизму. Наукова новизна роботи полягає в тому, що автором вперше здійснено спробу системного аналізу організованих владою масової дитячої безпритульності й смерті в роки Голодомору-геноциду. Висновки. Можемо стверджувати, що практично вся діяльність державних органів щодо подолання масового голоду й безпритульності дітей та підлітків у роки Голодомору-геноциду 1932-1933рр. зводилась до подолання вуличної безпритульності як соціального явища, шляхом вилучення дітей з вулиці, розміщення їх в непристосованих приміщеннях (майже не було інтернатних установ), повернення до родин, чи передачі на колективний та індивідуальний патронат. Лише частково такі заходи сприяли поліпшенню становища мізерної частини дітей, але докорінно вирішити цю проблему не могли. Окрім того, сталінський режим і не ставив перед собою таких першочергових завдань. Адже головною причиною зростання безпритульності були масовий голод селян України, спричинений його антилюдською політикою, спрямованою на ліквідацію українського селянства масовими репресіями й терором, пограбуванням продовольства, так званим розкуркуленням, що передбачало фрізичне знищення селянина-господаря $i$ його нащадків.

Ключові слова: діти, Голодомор-геноцид, безпритульність, бездоглядність.

Постановка проблеми. Тема Голодомору-геноциду з роками не втрачає своєї актуальності, а навпаки знаходяться все нові аспекти, які потребують комплексного й неупередженого дослідження. Зокрема, проблема безпритульних дітей, їх смертність у цей трагічний період життя українського народу не отримала свого самостійного дослідження, а побіжно розглядалася або у вивченні історії Голодомору загалом, або в контексті висвітлення політики комуністичного режиму щодо дітей упродовж 1920-1930-х рр. Ми ж акцентуємо увагу на становищі тих дітей, які не перебували в закладах державної соціальної опіки, а опинилися на вулиці у розпал сталінської політики винищення українських селян голодом.

Аналіз джерел та останніх досліджень. Проблема дитячої безпритульності $\epsilon$ важливою складовою вивчення державної політики вищого комуністичного керівництва СРСР стосовно українців. Варто зазначити, що досліджень з проблем безпритульності й бездоглядності дітей у 1932-1933 рр. не так багато, більшість із наукових праць присвячені періоду утвердження радянської влади в Україні в 1919-1920 рр. Основне місце у вивченні становища безпритульних дітей передусім займають документи і матеріали Державного архіву міста Києва (ДАК), Центрального державного архіву громадських об'єднань України (ЦДАГОУ) та Центрального державного архіву вищих органів влади і управління України (ЦДАВОВУ). Зокрема, у ЦДАВОВУ важливими для вивчення були справи фондів: Ф.166 - Народний Комісаріат освіти УСРР, Ф.264 - Всеукраїнське правління товариства «Друзі Дітей» при ВУЦВК, Ф.342 - Народний Комісаріат Охорони Здоров'я УРСР, у яких знаходимо важливу інфрормацію про становище безпритульних дітей, а також заходи місцевої влади, спрямовані на боротьбу з цим соціальним явищем, спровокованим московською владою. Важливим джерелом інформації $\epsilon$ збірники опублікованих документів і матеріалів [Брицький, 2013; Герасименко, Удовиченко, 2014; Кресіна, 1997; Пиріг, 1990; Пиріг, 2007; Сергійчук, 2016; Шаповал, 2007], а також комплексні праці з історії Голодомору та соціально-економічного становища українців у 1920-1930-х рр. [Конквест, 1993; Кульчицький, 2012; Марочко, 2008; Ревегук, 2016; Хорошевський, 2008]. Окрему 
увагу варто приділити науковій праці [Кульчицький, Шаталіна, 1989], в якій здійснено огляд становища українських дітей напередодні та в роки Голодомору-геноциду. Серед дослідників масової дитячої безпритульності в Радянській Україні у 1920-1930-х рр. слід виділити А. Зінченко, яка у своїй дисертаційній роботі розглянула сутність безпритульності як соціального явища в історичному контексті [Зінченко, 2002]. Питання створення та функціонування Всеукраїнського товариства «Друзі дітей» вивчав Т. Букрєєв [Букрєєв, 2013]. Шляхи подолання дитячої безпритульності в роки Голодомору-геноциду та роль у цьому процесі всеукраїнської громадської організації «Друзі дітей» спробувала визначити І. Шугальова [Шугальова, 2019].

Метою статті $€$ вивчення причин і масштабів поширення дитячої безпритульності й смертності, спричинених організованим сталінським режимом - Голодомором-геноцидом українського народу в 1932-1933 роках, та аналіз діяльності органів влади у їх подоланні.

Виклад основного матеріалу. Комуністичний режим вбачав дитячу безпритульність в Україні виключно наслідком діяльності царизму та розв'язаної ним Першої світової війни, ігноруючи при цьому війну більшовицького режиму за повалення влади УНР, масовий терор, репресії і депортації, пограбування продовольчих і матеріальних ресурсів України. Саме такий підхід зумовлював впровадження відповідних заходів боротьби з таким соціальним явищем ліквідацію самої безпритульності, а не причин, які її породжували [Зінченко, 2002 : 7]. У середині 20-х років унаслідок репресивної політики й продовольчого терору, злиденного життя населення збільшилася кількість безпритульних дітей, які мали батьків, але ті не мали змоги їх утримувати.

Наприкінці 1920-х рр., за даними соціологічного опитування, проведеного Народним комісаріатом освіти (НКО) Української РСР, серед 1100 вилучених з вулиці безпритульних - діти робітників, складали 35,4\%, селян - 47\%, службовців - 5,6\%, інших (кустарів, непрацюючих тощо) - 10,8\% [Артамонов, $1929: 80]$. Аналіз статистичних даних свідчить, що переважну більшість у середовищі безпритульних становили діти селян, яких влада винищувала Голодом 1921-1923 рр. і репресіями за спротив запровадженим комуністичним методам господарювання. Упродовж перших десятиліть функціонування радянської влади на території України більшість безпритульних накопичувалась у містах, що було обумовлено вище названими причинами i втечами родин, дітей і підлітків до міст, де вони могли знайти застосування своєї праці й вижити. Окрім того, проблему безпритульності влада намагалася вирішити переважно у містах i практично зовсім не торкнулася села, яке було постійним джерелом поповнення її чисельності. В офріційних документах Одеської області на початок 30-х років спостерігається значне зростання відсотка безпритульних дітей за рахунок голодного вимираючого села (на 50\%) та відсотка розкуркулених дітей (від 10 до 15\%) [ЦДАВОУ. Ф.166. Оп.10. Спр.444. Арк.97; ЦДАВОУ. Ф.264. Оп.1. Спр.479. Арк.127].

Голодування населення України, що розпочалося наприкінці 20-х - початку 30-х років, за офріційними документами трактувалося тільки як «харчові труднощі», хоч вже на початку 1930-х рр. закритими матеріалами ДПУ та ЦК КП(б)У визнавалися: голодування селян, підвищення смертності, випадки людоїдства і трупоїдства, епідемії, катастрофічне зростання дитячої бездоглядності й безпритульності. Архівні матеріали містять безліч документів, в яких відображені реальні факти становища українських селян і їх дітей [Панібудьласка, $1997: 211$ 215, 220-221, 224-225; Пиріг, 1990].

Голодні селяни, намагаючись врятувати своїх дітей від смерті, різними шляхами доправляли їх у міста, де залишали у людних місцях, вокзалах, поблизу держустанов, житлових будинків або просто на вулиці, 3 надією, що дітей підберуть добрі люди, або міліція та передадуть до притулку. Також багато дітей, переважно підлітків, після смерті батьків тікали у місто, де жебракували, займались крадіжками, ставали жертвами розбою і канібалів, помирали від голоду. Яскраво змальовує ситуацію свідчення вчителя І. Ткаченко з с. Пальчик, Тальнівського району Черкащини, який повідомляє: «У селах Тальнівського району є чимало родин, які не мають хліба, харчуються різними сурогатами... У більшості випадків так бідують одноосібні селянські господарства. Діти в цих родинах стають тягарем, не мають сил відвідувати школи. Місцеві організації не хочуть, а часто й не можуть допомогти цим дітям. Діти залишають батьків і йдуть жебраками. Цей рух дітей-жебраків зростає. Діти-жебраки не дістають допомоги від населення і цілими днями харчуються сурогатами, ходять кволі. Не можна спокійно дивитися як учні стають жебраками, вихованцями вулиці, безпритульними» [ЦЦАГОУ. Ф.1. Оп.20. Спр.5249. Арк.30.].

Голодомор-геноцид спричинив потужний спалах вуличної безпритульності, яка наприкінці 1920-х рр. за безпідставними висновками державних органів і громадських організацій почала потроху зникати. Зокрема, ЦК ЛКСМ України у рішенні від січня 1931 р. констатував, що безпритульність майже ліквідовано, а «... контингент сучасної вуличної безпритульності складається за рахунок втікачів з дитбудинків...» [ЦДАВОУ. Ф.264. Оп.1. Спр.267. Арк.65]. Насправді, інформація не відповідала дійсності. Вже за перше півріччя 1932 р. виявлено понад 
4,9 тис. бездомних підлітків, а наприкінці року їх було вже понад 6,3 тис. [Кульчицький, Шаталіна, $1991: 22]$. За соціальним складом переважну більшість безпритульних (понад 75\%) на початку 1930-х рр., за підрахунками Р. Конквеста, складали селянські діти [Конквест, $1993: 230]$.

У серпні 1931 р. Всеукраїнський центральний виконавчий комітет (ВУЦВК) ухвалив програму боротьби з дитячою безпритульністю, поставивши завдання ліквідувати ії до кінця 1932 р. Вона передбачала: розширення мережі інтернатних установ та забезпечення їх стабільного фінансування; поліпшення виробничої бази дитячих будинків шляхом прикріплення їх до промислових підприємств, шкіл фрабрично-заводського учнівства (ФЗУ), машиннотракторних станцій (МТC) та радгоспів; використання децентралізованих фондів для поліпшення постачання дитячих будинків; забезпечення 20 тис. школярів гарячими сніданками; для профілактики безпритульності впровадити систему прийняття до дитячих будинків бездоглядних дітей робітників та селян [ЦДАВОУ. Ф.264. Оп.1. Спр.547. Арк.76]. Проте, не дивлячись на затвердження програми, для ії практичного втілення не вистачало не лише коштів, а й бажання державного керівництва, яке не враховувало реальної трагічної ситуації, що склалася в республіці внаслідок «будівництва соціалізму» засобами жорстокої боротьби 3 його «ворогами»- селянами.

Безпритульність набувала в країні величезних масштабів, що не рахуватися з цим стало вже неможливим, а в умовах Голодомору вона набула соціально загрозливого характеру. Для подолання її при Наркоматі освіти УСРР у квітні 1932 р. був створений Центральний штаб з ліквідації безпритульності, до складу якого увійшли представники Наркомздоров'я, Наркомзабезпечення, Наркомпраці, Укрколгоспцентру, міліції, груп стрілецької охорони на транспорті, головував член колегії Наркомату освіти (НКО) Братун [ЦДАВОУ. Ф.166. Оп.10. Спр.426. Арк.38.]. Такі штаби діяли при відділах народної освіти в містах, обласних і районних центрах та керували обліком і виявленням безпритульних дітей.

Бригади, за участі представників міліції, вилучених на вулицях дітей тимчасово розміщували у так званих ізоляційних пунктах, у яких вони (через непристосованість, антисанітарний стан і перевантаженість) голодні, без медичної допомоги масово помирали [Марочко, 2008:40]. Зокрема, жахливі умови утримання дітей, їх голодне становище й поширення різних епідеміологічних хвороб були виявлені 19 лютого 1932 р. у процесі обстеження тимчасового притулку для безпритульних у Києві на Вознесенському узвозі, 4. В акті обстеження зазначалося наступне: «Безпритульні в кількості 160 дітей розташовані в двох кімнатах колишнього кінотеатру: одна кімната - балкон, інша - зал для глядача. У приміщеннях немає природного освітлення, воно освітлюється невеликими електричними лампочками, недостатніми для такого приміщення. У передній вибито шибки у вікнах, а в деяких немає і луток. Безпритульні скупчені по темних кутках, роздягнені, босі, брудні, не стрижені, завошивлені. Їм не проводили санобробку. Частина безпритульних лежить на брудній підлозі, а для іншої $є$ спільні нари без постільних речей. Повітря таке важке, що не можна дихати. Причиною $€$ те, що під сценою кутки забруднені людськими екскрементами (кал і сеча), крім того під стіною $є$ багато сміття. Каналізаційна мережа зіпсована» [ДАК. Ф.Р.323. Оп.1. Спр.67. Арк.38.]. Після проходження карантину безпритульних віком до 4-х років, хто залишився живим, передавали до будинків дитини, а старших направляли до дитячих будинків Наросвіти УСРР[ЦДАВОУ. Ф.342. Оп.14. Спр.215. Арк.29,33].

Важливим завданням було вилучення безпритульних з транспорту, яке ще у 1930 p. покладене на Стрілецьку охорону, працівники якої проводили перевірку потягів, виловлювали безпритульних на вокзалах, направляли їх до місцевих штабів з ліквідації безпритульності. Останні, спільно з органами міліції направляли їх у вагони-приймальники, місцеві біржі праці, дитячі будинки, а тих, хто мав родини, відправляли до батьків. Так, на Південно-Західній та Катеринославській залізницях впродовж червня-липня 1932 р. вилучено 3121 безпритульних дітей, з яких 1456 мали батьків [ЦДАВОУ. Ф.264. Оп.1. Спр.479. Арк.124.]. Через постійне зростання динаміки чисельності безпритульних на залізницях і транспортних шляхах місцеве керівництво застосовувало антилюдські методи їх утримання. Зокрема, на станції Полтава Південна дітей зачиняли у спецвагоні, розташованому на запасній колії, що фактично був перетворений на дитячу в'язницю. У ньому утримували близько 75 безпритульних дітей, яких іноді годували рідкою баландою. Як наслідок, більшість із них не витримували подібних умов і помирали [Ревегук, $2016: 277]$.

У травні 1933 р. за постановою ЦК КП(б)У «Про боротьбу з дитячою безпритульністю» розпочала свою діяльність Всеукраїнська комісія по боротьбі з безпритульністю, яку очолив О. Бронєвой [Пиріг, $2007: 836-838$ ]. Вона мала займатися організацією дитячих притулків у селах, притягати до відповідальності осіб, які не допомагали голодуючим, стримувати наплив безпритульних дітей до міст. 
Інформація про функціонування подібних комісій навпаки стимулювала селян направляти своїх дітей у великі міста Донбасу, Наддніпрянщини й особливо Харків і Київ з надією, що їх врятують від голодної смерті. Натомість там їх виловлювали спеціальні групи за участі працівників міліції і органів ДПУ й відправляли в бараки смерті. Зокрема, на Холодній Горі в Харкові, на соломі під навісами, організували пристанище для 8000 осіб, значна частина з яких діти. Щоденно там помирали від 80 до 100 осіб [Шаповал, $2007: 158-165$ ]. У Цитовських і Салтовських бараках розміщували дітей віком до чотирьох років. Міський відділ охорони здоров'я у доповідній записці вказував, що діти у бараках надзвичайно виснажені, щомісяця їх помирає більше третини. Не зважаючи на це, кількість дітей, які перебували в бараках, невпинно зростала. Зокрема, у Салтовських бараках, станом на 14 травня 1933 р., знаходилося 450 дітей, а вже на 1 червня того ж року - 900 [Кульчицький, 2012 : 329-330]. У листі голові ДПУ УСРР В.Балицькому від 5 червня 1933 р. начальник Харківського обласного відділу ДПУ 3. Кацнельсон інфрормував про стрімке і масове поширення голоду, що спричинив розмах дитячої безпритульності в Харкові й області. Як зазначається в листі, унаслідок значного посилення напливу в місто безпритульних, бездоглядних і голодних, за січень-лютий з вулиць підібрано 373 дітей і підлітків, відповідно за березень-квітень - 1806, у травні - 6378, за три дні червня - 606 [Хорошевський, 2008 : 923]. Окрім того, комісією Бронєвого на вокзалах виловлено 10 тис. дітей. Лише 657 із них були направлені до дитячих будинків, інші - у спеціальні розподільники й назад на села, що свідчило про катастрофічний стан системи охорони дитинства в радянській Україні [Герасименко, Удовиченко, 2014 : 196-197, 202].

У травні 1933 р. у розподільниках, бараках і дитбудинках Харкова чекали смерті понад 27 тис. дітей. ЦК КП(б)У замість того, щоб рятувати їх, 1 серпня 1933 р. ухвалив постанову про масове повернення безпритульних дітей з міст у голодні вимираючі 55 тис. сіл, селяни яких уже з весни 1931 р. до зими 1934 р. масово голодували [Веселова, Марочко, Мовчан, 2000 : 128129]. Не менш жахливим було становище дітей на Запоріжжі. Лише впродовж травня 1932 жовтня 1933 рр. у Запоріжжі, в невеликому будинку немовлят, що складався з двох палат, одна - для дівчаток і друга - для хлопчиків, померло майже 800 безпритульних дітей віком від двох до трьох років. Поряд з сиротинцем були розташовані міський комітет КПП(б)У, міськвиконком, ДПУ, всі органи так званого правосуддя, інші державні установи, будинки, де жила найзабезпеченіша частина населення міста і області. У пайки службовців та їх родин, які перебували на державному забезпеченні, входили, м'ясо, жири, свіжа риба, оселедці, цукор, яйця, молоко, чай та інші продукти. До того ж, їх постійно збільшували. Натомість ніхто з них, знаючи про трагічний стан немовлят, не допомогли їм. Хіба це не геноцид? [Бернарде Шоу..., 2015].

Становище дітей в дитячих будинках, інтернатах, колекторах-розподільниках, колоніях було жахливим. Після виявлення й виловлювання безпритульних дітей на Чернігівщині у 1933 p. в Бахмачському районі в розподільнику райцентра налічувалося 146 дітей, із них 47 перебували в лікарні, а в Густинській дитячій колонії 155 безпритульних. Начальник районного управління ДПУ Британ характеризував їх стан як «надзвичайно жахливий»: «простирадл, рушників немає зовсім, ковдр вісім, солом'яних матраців мало (сплять на них упоперек четверо), стіл один на 20 - 40 дітей... Дітям дають 200 г. хліба на добу... Крупи, цукру, жирів, риби, молока немає». Голодні, напівроздягнені, завошивлені, вони блукали по городах селян і міщан, об”ївшись зелені, помирали [Шкварук, $1999:$ 77].

Блокада московською владою 180 районів України ще в 1931 р. спричинила катастрофічне становище й дитячих установ, що і так не мали жодних запасів продовольства. Дніпровський райвиконком у телеграмі до президії ВУЦВК УРСР просив дати хліба голодуючим дітям колонії містечка Кам'янка: «... 230 дітей зняті 3 централізованого продовольства, децентралізоване постачання заборонено, місцевих резервів немає. Діти лишаються зовсім без хліба...» [Улянич, 2004 : 63]. Звичайно, не було в дитячій колонії й інших продуктів харчування. Переповнені дитячі установи відмовлялися приймати безпритульних, а ті, кого повертали до батьків, часто не заставали їх живими, або вони були не в змозі прогодувати своїх дітей. За таких умов ці діти знову йшли до міста, поповнюючи лави жебраків та безпритульних, вимушені були вчиняти дрібні крадіжки в селах і містах, за що їх жорстоко карали.

Свідоме, масове й дике пограбування селян кремлівським режимом спричинило збільшення крадіжок, насильства й вбивств у селах і містах, поширилися самосуди та людоїдство, зокрема і дітей. У селі Івангород Бахмачського району Чернігівської області 10річному хлопчику на городі Уляни Мухи відрубали обидві ноги, іншого вбили. Кандидат у члени ВКП(б) Кузьма Тарасенко, мешканець села Комарівка Ніжинського району, зарубав сокирою 14 річного Женю Сидорка, запідозривши його у крадіжці п'ятьох курей. Такі злочини були в кожному селі і, як правило, смерть грабіжників не реєстрували, а вбивць не судили [Шкварук, 1999 : 76].

Становище дітей в Україні набуло ще більше трагічного характеру після прийняття ЦВК і РНК СРСР 7 серпня 1932 р. закону про охорону державного майна, написаного власноручно 
Й. Сталіним, згідно з яким за розкрадання урожаю, худоби й іншого майна розстрілювали, а за незначні крадіжки (пригорщі зерна, збирання колосків) позбавляли волі на 10 років навіть дітей віком від 12 років [Марочко, Мовчан, $2008: 120]$.

Збільшення кількості правопорушень серед неповнолітніх стало прямим наслідком появи та поширенням масової вуличної безпритульності, викликаної Голодомором-геноцидом. За матеріалами комісії у справах неповнолітніх при Київському відділі освіти на середину 1933 р. правопорушення неповнолітніх розподілялися наступним чином: проти майна - 981, проти особи - 14, проти держави - 6 справ [ЦДАВОУ. Ф.166. Оп.11. Спр.297. Арк.1]. У загальній чисельності неповнолітніх правопорушників значно зріс відсоток дітей селян: з $5 \%$ на початок 1931 р. до $17,5 \%$ на 1933 р. Поширилася також тенденція, що набувала стійкого характеру зростання відсотку правопорушень серед дітей, які мали обох батьків (46,5\%), що стало наслідком голоду і зростання дитячої бездоглядності [ЦДАВОУ. Ф.166. Оп.10. Спр.438. Арк.6]. Голодомор-геноцид на Київщині охопив усі 42 райони, де за далекими від реальності даними голодували селяни 829 сіл, із них понад 112,2 тис. дітей [Пиріг, 1993 : 57-59].

Перевантаженість дитячих будинків підлітками гальмувала процес вилучення безпритульних з вулиці, кількість яких постійно збільшувалась. Під керівництвом Центрального штабу до 1 грудня 1932 р. у Донецькій, Київській, Харківській областях та в Молдавській АСР виявлено й вилучено з вулиці ще 6334 безпритульних дітей та працевлаштовано 3 тис. підлітків з дитячих будинків [ЦДАВОУ. Ф.166. Оп.10. Спр.426. Арк.38].

На початку 1932 р. державна влада провела реорганізацію структури органів, які займалися ліквідацією безпритульності та бездоглядності дітей і допомогою сиротам. У листопаді 1932 р. Центральна комісія допомоги дітям (ЦКДД) була ліквідована, а ії функції перейшли до товариства «Друзі дітей» [Про організацію..., 1932 : 2-4]. Згідно з постановою вся оперативна робота з ліквідації безпритульності покладалася на Наркомат освіти, в системі якого діяв Центральний штаб з ліквідації безпритульності. У кожному районі міста штаби 3 громадськими ударними бригадами, керовані органами міліції й ДПУ, виловлювали бездоглядних дітей на вулицях та направляли їх до карантинних бараків, колекторів, а тих, хто вижив - до притулків, дитбудинків й назад до села. Варто зазначити, що на активну допомогу «Друзів дітей» у роки Голодомору не доводилось розраховувати, бо робітники та селяни неспроможні були прогодувати свої родини, а саме з їх внесків складалася переважна частина коштів товариства. Ці організаційні хиби, безумовно, тільки ускладнювали вирішення ситуації з безпритульністю та бездоглядністю дітей в Україні.

Всеукраїнська громадська організація «Друзі дітей» на чолі 3 почесним головою Г. Петровським, що розподілялася на обласні та районні правління з доволі однотипною структурою, намагалася організувати грошову допомогу безпритульним голодуючим дітям Вінницької та Київської областей, зокрема зібрала для них 290 тис. крб. (з них 150 тис. з власних коштів і 140 тис. 3 фонду ім. Леніна) [ЦДАВОУ. Ф.264. Оп.1. Спр.546. Арк.24]. За неповними даними, силами товариства у 1932 р. вилучено з вулиці 1412 безпритульних дітей, із них: у Києві - 350, Умані - 240, АМСРР - 180, Дніпропетровську - 472, Сталіно - 167 [ЦДАВОУ. Ф.264. Оп.1. Спр.479. Арк.193].

Процес ліквідації дитячої безпритульності на початку 1930-х рр. був ускладнений організаційними змінами в органах боротьби з безпритульністю. Відповідно до постанови ЦК КП(б)У «Про боротьбу з дитячою безпритульністю» від 6 травня 1933 р. при РНК УРСР утворено Всеукраїнську, а при облвиконкомах - місцеві надзвичайні комісії боротьби 3 безпритульністю та жебрацтвом, які мали організувати допомогу осиротілим та покинутим дітям через створення сільських дитячих приймальників, організацію харчпунктів при школах тощо. Постанова зобов'язувала комісію здійснити рішучі дії для очистки Харкова, Києва, Одеси та інших міст від «бродяжнических элементов» [Пиріг, 1990 : 505-507]. Вже наприкінці липня 1933 р. голова Всеукраїнської комісії звітував РНК УСРР про виконану роботу. За даними обласних комісій, загальна кількість вилучених із вулиці безпритульних в Україні на 5 липня 1933 р. становила 158090 осіб, з них повернено до батьків - 20143, влаштовано до сільських дитячих установ - 83016, до міських інтернатних установ - 54921 дитину [ЦДАГОУ. Ф.1. Оп.20. Спр6263. Арк.24].

У липні 1933 р. товариство «Друзі дітей» провело місячник збору коштів на боротьбу з безпритульністю. Передбачалося зібрання ще додаткових 5 млн. крб., натомість на 20 липня 1933 р. вдалося зібрати лише біля 1,7 млн. крб. [ЦДАГОУ. Ф.1. Оп.20. Спр6263. Арк.12, 25]. За підрахунками дослідників, Всеукраїнське товариство «Друзі дітей» у 1929 р. із різними фрормами соціально-профрілактичних заходів охопило 48 тис. безпритульних дітей, у 1932 р. - 82 тис., у 1933 р. - 120 тис. дітей [Букрєєв, 2013 : 27-34.]. Можемо чітко простежити стрімке збільшення чисельності безпритульних у роки Голодомору-геноциду, що фактично призупинило діяльність товариства, оскільки воно вже не було спроможним подолати катастрофічні соціальні й демографрічні прояви його наслідків. 
Намагання влади протистояти розмаху дитячої безпритульності ускладнювало те, що не було централізованої установи, яка б опікувалася порушеним питанням, тому статистика також була роздрібнена, розмита й необ'єктивна [Шугальова, 2019 : 213]. Діти віком до чотирьох років перебували під відповідальністю Наркомздоров'я, дошкільного та шкільного віку - юрисдикцією Наркомосвіти, підлітки 15-18 років - Наркомпраці, на транспорті боротьбу з безпритульністю проводив транспортний Червоний Хрест «Друзів дітей» [ЦДАВОУ. Ф.264. Оп.1. Спр.546. Арк.15]. Питаннями щодо захисту дітей в областях займалася низка інших організацій, зокрема, відділи охматдиту та органи міської допомоги дітям, нескоординованість дій яких призводила до численних непорозумінь й незначних результатів.

Місцеві органи влади намагалися власними зусиллями врятувати дітей від голоду. Так, при відділі народної освіти Київської міськради ще у листопаді 1931 р. був створений комітет, районні штаби й організовано 45 бригад, які займалися ліквідацією безпритульності [Досвід боротьби..., 1932 : 19]. Київський облвиконком на початку 1933 р. за рахунок власних коштів відкрив харчові пункти для 9350 дітей області [Панібудьласка, $1997: 238$ ]. Проте вже у червні 1933 р. Київська міська рада заборонила всім підпорядкованим сільським і селищним радам направляти безпритульних дітей до міста, а залишати в дитячих установах села, використовуючи для цього продовольчу допомогу, яка надавалася селу від міськради, а також попереджувала, що надіслані діти будуть повернуті назад, при цьому голів сільських рад буде притягнуто до адміністративної відповідальності [ЦДАВОУ. Ф.1. Оп.9. Спр.148. Арк.116]. Насправді ізольовані сталінським режимом села України ніякої допомоги від міськрад не отримували.

Масова дитяча безпритульність стала яскравим виявом і доказом соціальної катастрофи українського суспільства, що спричинив геноцид московської комуністичної влади українських селян у 1932-1933 рр.. Як справедливо зазначає відомий дослідник Голодомору-геноциду В. Марочко, явище масової дитячої безпритульності виявилося «живим барометром» великої руїни генофонду нації, тому що переважна більшість дітей помирала, значна частина була вимушена вдатися до жебрацтва, деякі перетворювалися на людоїдів, деградуючи фізично і морально [Кульчицький, 2012 : 329]. Смертність дітей в Україні віком 5-15 років, яких на початку 1933 р. налічувалося понад 8106 тис., становила понад 50 \% від загальної кількості померлих [Сергійчук, 2018].

Радянська влада звернула увагу на проблему подолання безпритульності тільки у 1933 р., коли юрби дітей перетворилися на пряму загрозу для життєдіяльності міст, завдаючи відчутного удару по ідеологічно створеній брехливою пропагандою моделі «переваг і тріумфу» соціалістичного ладу в очах іноземців. Проте реальне становище українського населення, зокрема селян, все ж знайшло правдиве висвітлення серед світової громадськості. Так, італійський консул у Харкові С. Граденіго у своїх листах 1933 р. повідомляв Амбасаду Італії в Москві про геноцид українців, зокрема, описував жахливе становище безпритульних дітей. В одному з багатьох повідомлень він пише: «Дитина смоктала молоко з груді мертвої матері, обличчя ії̈ було сірого кольору. Люди казали: це пуп'янки соціалістичної весни... Лише тиждень тому було організовано службу збору покинутих дітей. Адже, крім селян, які сунуть у міста, більше не маючи на селі жодної надії вижити, $є$ також діти, яких батьки приводять сюди і кидають, а самі повертаються у своє село, щоб там померти. Вони сподіваються, що в місті про їхніх дітей хтось подбає. Але, ще тиждень тому вони лежали, плачучи, на кожному розі, на хідниках, повсюди. Можна було побачити десятирічних дівчаток, які няньчили дітей 4 або 3 років. Коли наставала ніч, вони накривали їх своєю шаллю чи пальтом або ж влягалися спати на землю, поставивши поруч бляшанку для милостині. Тиждень тому були мобілізовані двірники, які у білих фрартухах ходять містом, збирають дітей і приводять їх до найближчого відділка міліції, що часто-густо супроводжується розпачливими сценами, криками і плачем: «Не хочу у бараки смерті, залиште мене спокійно вмерти». Десь близько півночі їх починають вантажівками перевозити на товарну станцію Сєверодонецька, туди звозять також дітей підібраних у селах, знайдених у поїздах... Розпухлих везуть товарним поїздом за місто і залишають за 50-60 км, щоб вони там померли, не на очах у всіх... По прибутті на місце викопують великі ями і виносять з вагонів усіх мертвих. Мене запевняють, що до трупів не дуже придивляються і буває, що той, кого кинули в яму, приходить до тями i в останньому сплескові життєвих сил починає ворушитися, але це не перериває праці гробарів. Ці подробиці я почув від санітарів і можу гарантувати їх автентичність» [Шаповал, $2007: 161-163$ ]. Фактично С. Граденіго всього на декількох аркушах листа відтворив усе жахіття років Голодомору-геноциду, організованого комуністичним режимом в Україні.

Висновки. Отже, боротьба з безпритульністю, що стала наслідком навмисно організованого Голодомору-геноциду, продовжувалася такими традиційними заходами, як вилучення безпритульних з вулиці та розміщення їх у розподільниках, бараках, частково - у дитячих будинках, поверненням у села, звідкіля вони втекли від голодної смерті. Незначну 
кількість їх влаштовували до державного й індивідуального патронатів. У процесі вирішення цієї важливої проблеми влада вдавалася до адміністративних і каральних дій: ізоляції областей і районів, що не виконали планів хлібозаготівлі, трудової мобілізації підлітків, примусового патронату дітей на селі, а в містах - відлову і розміщення їх у спеціальних колекторах, де вони масово вимирали. Нечисленні дитячі будинки не були забезпечені ні матеріально-побутовими речами, ні продуктами харчування, прирікаючи тим самим дітей на смерть.

Натомість сталінський режим продовжував проголошувати на весь світ брехню про «... досягнення соцбудівництва, піднесення матеріального й культурного стану робітників, колгоспників, широке запровадження дошкільного виховання, запровадження загального обов'язкового навчання, що забезпечують значне поліпшення стану дитинства й створюють всі умови для остаточної ліквідації безпритульності, широкої роботи серед дітей і боротьби з бездоглядністю» [ЦДАВОУ. Ф.166. Оп.10. Спр.438. Арк.5].

Так, на початок 1930-х рр. в Україні з'явилася нова хвиля безпритульних дітей, що була породжена жорстокою політикою сталінського комуністичного режиму, зокрема масовими репресіями, колективізацією, піком якої став Голодомор-геноцид українських селян. Саме діти з селянських родин вже у 1931 р. наповнювали вулиці міст з надією отримати порятунок від голодної смерті. Коли ж дитяча безпритульність набула серйозних масштабів, ситуація вийшла 3-під контролю й стала загрожувати функціонуванню міської інфрраструктури, влада почала вирішувати проблему. Заборона відправляти дітей до міст, підбір безпритульних на вулицях i розподіл їх по ізоляційних пунктах, які перетворювалися на розплідники епідеміологічних Хвороб, фрактично позбавляли шансів величезну частину дітей дочекатися на переведення до закладів соціальної опіки і тільки підвищували показники дитячої смертності. Створені державою спеціальні комісії та благодійні товариства не могли впоратися із таким загрозливим соціальним явищем, адже голодні 1932-1933 рр. тільки ускладнювали становище дітей та породжували загрозливі масштаби безпритульності.

Подяка. Висловлюю щиру вдячність членам редакційної колегії журналу за конструктивні консультації, надані під час підготовки статті до друку.

Фінансування. Авторка не отримала фрінансової підтримки для проведення досліджень й публікації статті.

\section{Джерела та література:}

Артамонов, П. (1929). Задачи борьбы с детской беспризорностью и детдом (К партсовещанию по вопросам народного образования). Народное просвещение, 1, 78-89.

Бернарде Шоу... (2015). Бернарде Шоу, ласкаво просимо у пекло! До 82-х роковин відвідання Бернардом Шоу СРСР. День, 31 липня - 1 серпня.

Брицький, П. П. (2013). Голодомори в радянській Україні. Чернівці: Чернівецький національний університет, $310 \mathrm{c}$.

Букрєєв, Т. Б. (2013). Створення та функціонування Всеукраїнського товариства «Друзі дітей» у 1920-ті роки. Науково-дослідна робота молодих учених: стан, проблеми, перспективи: матеріали всеукраїнської науково-практичної інтернет-конференції (сс. 27-34). Херсон.

Веселова, О. М., Марочко, В. І., Мовчан, О. М. (2000). Голодомори в Україні: 1921-1923, 19321933, 1946-1947: Злочини проти народу. 2-е вид., доп. Київ, Нью-Йорк: Вид-во М.П. Коць, 274 с.

Герасименко, М., Удовиченко, В. (Упоряд.). (2014). Геноцид в Україні 1932-1933 рр. за матеріалами кримінальної справи № 475. Київ: ТОВ Друкарня «Бізнесполіграфра», 560 с.

ДАК - Державний архів м. Києва.

Досвід боротьби... (1932). Досвід боротьби з дитячою безпритульністю. Друг dimeй, 17, С. 19.

Зінченко, А. Г. (2002). Дитяча безпритульність в радянській Україні в 20-х - першій половині 30-х років XX століття: авторефрерат дисертації кандидата історичних наук: 07.00.01. Одеса, 17 с.

Конквест, Р. (1993). Жнива скорботи: радянська колективізація і голодомор: пер. з англ. Київ: Либідь, 280 с.

Кульчицький, С. В. (відп. ред.). (2012). Українське радянське суспільство 30-х рр. XX ст.: нариси повсякденного життя. Київ: Інститут історії України НАН України, 786 с.

Кульчицький, С. В., Шаталіна, Є. П. (1989). Становище дітей на Україні у 1931-1933 роках. Документальна розповідь. Київ: Ін-т історії АН УРСР, 26 с.

Марочко, В., Мовчан, О. (2008). Голодомор 1932-1933 років в Україні: Хроніка. Київ: Видавничий дім «Києво-Могилянська академія», 294 с.

Марочко, В.І. (відп. ред.). (2008). Національна книга пам'яті жертв Голодомору 19321933 років в Україні. Місто Київ. Київ: Фенікс, 584 с.

Панібудьласка, В.Ф. (ред.). (1997). Національні процеси в Україні: історія і сучасність. Документи і матеріали: довідник (Ч.2). Київ: Вища школа, 704 с. 
Пиріг, Р. Я. (1993). Наслідки тоталітаризму початку 1930-х років на Київщині. Золоті ворота, 4 , 46-67.

Пиріг, Р. Я. (Упоряд.). (1990). Голод 1932-1933 рр. на Україні: очима істориків, мовою документів. Київ: Політвидав України, 605с.

Пиріг, Р. Я. (Упоряд.). (2007). Голодомор 1932-1933 років в Україні: документи і матеріали. Київ: Вид. дім «Києво-Могилянська академія», 1128 с.

Про організацію... (1932). Про організацію системи роботи у справі допомоги дітям. Постанова ВУЦВК і РНК УРСР. Збірник законів та розпоряджень робітничо-селянського уряду України, 3З, C. 2-4.

Ревегук, В. (2016). Полтавщина. Протибільшовицький Рух опору 20-30-х років XX століття: Нариси історії. Полтава: Полтавський літератор, 306 с.

Сергійчук, В. І. (2016). Голодомор 1932-1933 років як геноцид українства. Видання четверте, доповнене. Вишгород: ПП Сергійчук М.І., 320 с.

Сергійчук, В. І. (2018). Ушанувати всіх невинних убієнних. Голос України, 88.

Улянич, В. І. (2004). Терор голодом і повстанська боротьба проти геноциду українців у 19231933 роках. Київ: ДП «Експрес-Поліграфф, 82 с.

Хорошевський, А. Ю. (відп. ред.). (2008). Національна книга пам'яті жертв Голодомору 19321933 років в Україні. Харківська область. Харків: Фоліо, 1023 с.

ЦДАВОУ - Центральний державний архів вищих органів влади і управління України.

ЦДАГОУ - Центральний державний архів громадських об'єднань України.

Шаповал, Ю. (наук. ред.). (2007). Листи з Харкова. Голод в Україні та на Північному Кавказі в повідомленнях італійських дипломатів 1932-1933 роки. Харків: Фоліо, 255 с.

Шкварук, В. (1999). Голодомор 1932-1933 годов на Черниговщине (Историкопублицистическое исследование). Из. второе доп. Чернігів: Нова хвиля, 98 с.

Шугальова, І. (2019). «Друзі» із каменем за пазухою (до історії створення та діяльності в роки Голодомору Всеукраїнського товариства «Друзі дітей»). Scriptorium nostrum, 1. С. 205-222. Режим доступу: http://sn.kspu.edu/index.php/sn/article/view/23/24

\section{Ирина Батюк}

Национальный педагогический университет имени М. П. Драгоманова аспирантка (Украина)

\section{Массовая беспризорность детей Украины в годы Голодомора-геноцида 1932-1933 гг.}

Аннотация. Цель статьи. На основе комплексного анализа архивных источников, опубликованных документов и материалов, а также современных исследований историков, осветить явление массовой детской беспризорности в Украине в период Голодоморагеноцида, организованного российским коммунистическим режимом в 1932-1933 г2. Проанализировать деятельность органов государственной власти и созданных ими комиссий в оказании помощи беспризорным детям в процессе преодоления данного трагического социального явления. Методология исследования основана на сочетании общенаучных (анализа и синтеза), специально-исторических (проблемно-хронологического, историко-системного) методов и принципов научности и историзма. Научная новизна работы заключается в том, что автором впервые предпринята попытка системного анализа организованных властью массовой детской беспризорности и смерти в годы Голодомора-геноцида. Выводы. Можем утверждать, что практически вся деятельность государственных органов по преодолению массового голода и беспризорности детей и подростков в период Голодомора-геноцида 1932-1933 ге. сводилась к преодолению уличной беспризорности, как социального явления, путем изъятия детей с улицы, размещение их в неприспособленных помещениях (отсутствие интернатных учреждений), возвращение к семьям или передачи на коллективный и индивидуальный патронат. Частично такие меры способствовали улучшению положения мизерной части детей, но в корне решить эту проблему не могли, кроме того сталинский режим и не ставил перед собой таких первоочередных задач. Ведь главной причиной роста беспризорности были массовый голод крестьян Украины, вызванный его античеловеческой политикой, направленной на ликвидацию украинского крестьянства массовыми репрессиями и террором, ограблением продовольствия так называемым раскулачиванием, которое предусматривало фризическое уничтожение крестьянина-хозяина и его потомков.

Ключевые слова: дети, Голодомор-геноцид, беспризорность, безнадзорность. 


\author{
Iryna V. Batiuk \\ National Pedagogical Dragomanov University \\ postgraduate (Ukraine)
}

\title{
Mass Homelessness of Ukrainian Children during the Holodomor-Genocide in 1932-1933s
}

\begin{abstract}
The aim of the article. Based on a comprehensive analysis of archives, published documents, and materials, as well as current historical studies, the phenomenon of mass child homelessness in Ukraine during the Holodomor-Genocide which organized by the Russian communist regime in 1932-1933s is highlighted. The aim of the article is to analyze the activities of state authorities and their commissions in assisting homeless children in the process of overcoming this tragic social phenomenon. The research methodology is based on a combination of general scientific (analysis and synthesis), special and historical (problem-chronological, historical-systematic) methods and principles of scientificity and historicism. The scientific novelty of the study lies in the fact that the author first attempted a systematic analysis of the mass child homelessness and death caused by the authorities for the first time in the history of Ukraine during the Holodomor-Genocide. Conclusions. We can state that almost all of the activities of state authorities to overcome mass starvation and homelessness of children and adolescents during the Holodomor-Genocide of 19321933s consisted in overcoming street homelessness as a social phenomenon by removing children from the streets, placing them in unsuitable premises due to a lack of residential care facilities, returning them to families or placing them under collective and individual foster care. Such measures only partially served to improve the situation of a tiny proportion of children, but could not address the issue fundamentally, since it was not a primary concern of the Stalin's regime itself. After all, the main reason for the growth of homelessness was the mass starvation of the Ukrainian peasants caused by his anti-human policy of liquidating the Ukrainian peasantry through mass repression and terror and plundering food by the so-called "dekulakization", which implied the physical destruction of the peasant and his descendants and further enslavement of those who remained, and driving them into collective farms.
\end{abstract}

Key words: children, Holodomor-Genocide, homelessness, child negligence.

\section{References:}

Artamonov, P. (1929). Zadachi borby s detskoy besprizornostyu i detdom (K partsoveshchaniyu po voprosam narodnogo obrazovaniya) [The tasks of combating homeless children and the orphanage (To the party meeting on public education)]. Narodnoe prosveshchenie - Public education, 1, 78-89. [in Russian].

Bernarde Shou... (2015). Bernarde Shou, laskavo prosymo u peklo! Do 82-kh rokovyn vidvidannja Bernardom Shou SRSR [Bernard Shaw, welcome to the hell! To the 82nd anniversary of Bernard Shaw's visit to the USSR]. Denj-Day, 31 lypnja - 1 serpnja. [in Ukranian].

Brycjkyj, P.P. (2013). Gholodomory v radjansjkij Ukrajini [Famines in the Soviet Ukraine]. Chernivci: Chernivecjkyj nacionaljnyj universytet, 310 p. [in Ukranian].

Bukrjejev, T.B. (2013). Stvorennja ta funkcionuvannja Vseukrajinsjkogho tovarystva «Druzi ditej»u 1920 -ti roky [Establishment and functioning of the All-Ukrainian Society «Friends of Children» in the 1920s]. Naukovo-doslidna robota molodykh uchenykh: stan, problemy, perspektyvy: materialy vseukrajinsjkoji naukovo-praktychnoji internet-konferenciji (pp. 27-34). Kherson. [in Ukranian].

CDAGhOU - Centraljnyj derzhavnyj arkhiv ghromadsjkykh ob'jednanj Ukrajiny [Central State Archives of Public Organizations].

CDAVOU - Centraljnyj derzhavnyj arkhiv vyshhykh orghaniv vlady i upravlinnja Ukrajiny [Central State Archive of the highest authorities and administration]

DAK - Derzhavnyj arkhiv m. Kyjeva [State Archive of Kyiv].

Dosvid borotjby... (1932). Dosvid borotjby z dytjachoju bezprytuljnistju [Experience in combating child homelessness]. Drugh ditej - Friend of children, 17, P. 19. [in Ukranian].

Gherasymenko, M., Udovychenko, V. (Uporjad.). (2014). Ghenocyd v Ukrajini 1932-1933 rr. za materialamy kryminaljnoji spravy № 475 [Genocide in Ukraine in 1932-1933 according to the materials of the criminal case № 475]. Kyjiv: TOV Drukarnja «Biznespolighrafa», 560 p. [in Ukranian].

Khoroshevsjkyj, A.Ju. (vidp. red.). (2008). Nacionaljna knygha pam'jati zhertv Gholodomoru 19321933 rokiv $v$ Ukrajini. Kharkivsjka oblastj [National book of remembrance for the victims of the Holodomor of 1932-1933 in Ukraine. Kharkiv region]. Kharkiv: Folio, 1023 p. [in Ukranian].

Konkvest, R. (1993). Zhnyva skorboty: radjansjka kolektyvizacija i gholodomor: per. z anghl [The Harvest of Sorrow: Soviet Collectivization and the Terror-Famine]. Kyjiv: Lybidj, 280 p. [in Ukranian]. Kuljchycjkyj, S.V. (vidp. red.). (2012). Ukrajinsjke radjansjke suspiljstvo 30-kh rr. XX st.: narysy povsjakdennogho zhyttja [Ukrainian Soviet society in the 1930s: essays on everyday life]. Kyjiv: Instytut istoriji Ukrajiny NAN Ukrajiny, 786 p. [in Ukranian]. 
Kuljchycjkyj, S.V., Shatalina, Je.P. (1989). Stanovyshhe ditej na Ukrajini u 1931-1933 rokakh. Dokumentaljna rozpovidj [The situation of children in Ukraine in 1931-1933. Documentary story.]. Kyjiv: In-t istoriji AN URSR, 26 p. [in Ukranian].

Marochko, V., Movchan, O. (2008). Gholodomor 1932-1933 rokiv v Ukrajini: Khronika [The Holodomor of 1932-1933 in Ukraine: Chronicle]. Kyjiv: Vydavnychyj dim «Kyjevo-Moghyljansjka akademija», 294 p. [in Ukranian].

Marochko, V.I. (vidp. red.). (2008). Nacionaljna knygha pam'jati zhertv Gholodomoru 1932-1933 rokiv $v$ Ukrajini. Misto Kyjiv [National book of remembrance for the victims of the Holodomor of 1932-1933 in Ukraine. The city of Kyiv]. Kyjiv: Feniks, 584 p. [in Ukranian].

Panibudjlaska, V.F. (red.). (1997). Nacionaljni procesy v Ukrajini: istorija i suchasnistj. Dokumenty $i$ materialy: dovidnyk (Ch.2) [National processes in Ukraine: history and modernity. Documents and materials: reference book]. Kyjiv: Vyshha shkola, 704 p. [in Ukranian].

Pro orghanizaciju... (1932). Pro orghanizaciju systemy roboty u spravi dopomoghy ditjam. Postanova VUCVK i RNK URSR [About the organization of the system of work in the case of helping children. Resolution of the All-Ukrainian Central Executive Committee and the Radnarkom of the USSR]. Zbirnyk zakoniv ta rozporjadzhenj robitnycho-seljansjkogho urjadu Ukrajiny - Collection of laws and orders of the workers and peasants government of Ukraine, 33, P. 2-4. [in Ukranian].

Pyrigh, R.Ja. (1993). Naslidky totalitaryzmu pochatku 1930-kh rokiv na Kyjivshhyni [Consequences of totalitarianism of the early 1930s in Kyiv region]. Zoloti vorota - The Golden Gate, 4, P/ 46-67. [in Ukranian].

Pyrigh, R.Ja. (Uporjad.). (1990). Gholod 1932-1933 rr. na Ukrajini: ochyma istorykiv, movoju dokumentiv [The famine of 1932-1933 in Ukraine: through the eyes of historians, in the language of documents]. Kyjiv: Politvydav Ukrajiny, 605 p. [in Ukranian].

Pyrigh, R.Ja. (Uporjad.). (2007). Gholodomor 1932-1933 rokiv v Ukrajini: dokumenty i materialy [The Holodomor of 1932-1933 in Ukraine: documents and materials]. Kyjiv: Vyd. dim «KyjevoMoghyljansjka akademija», 1128 p. [in Ukranian].

Reveghuk, V. (2016). Poltavshhyna. Protybiljshovycjkyj Rukh oporu 20 - 30-kh rokiv XX stolittja: Narysy istoriji [Poltava region. Anti-Bolshevik resistance movement of the 1920s and 1930s: Essays on history]. Poltava: Poltavsjkyj literator, 306 p. [in Ukranian].

Serghijchuk, V.I. (2016). Gholodomor 1932-1933 rokiv jak ghenocyd ukrajinstva [The Holodomor of 1932-1933 as a genocide of Ukrainians]. Vydannja chetverte, dopovnene. Vyshghorod: PP Serghijchuk M.I., 320 p. [in Ukranian].

Serghijchuk, V.I. (2018). Ushanuvaty vsikh nevynnykh ubijennykh [Honor all innocent victims]. Gholos Ukrajiny - Voice of Ukraine, 88. [in Ukranian].

Shapoval, Ju. (nauk. red.). (2007). Lysty z Kharkova. Gholod v Ukrajini ta na Pivnichnomu Kavkazi v povidomlennjakh italijsjkykh dyplomativ 1932-1933 roky [Letters from Kharkov. Famine in Ukraine and the North Caucasus in the reports of Italian diplomats 1932-1933]. Kharkiv: Folio, 255 p. [in Ukranian].

Shkvaruk, V. (1999). Gholodomor 1932-1933 ghodov na Chernyghovshhyne (Ystorykopublycystycheskoe yssledovanye) [The Holodomor of 1932-1933 in the Chernihiv Region (Historical and Publicistic Research)]. Yz. vtoroe dop. Chernighiv: Nova khvylja, 98 p. [in Russian].

Shughaljova, I. (2019). «Druzi» iz kamenem za pazukhoju (do istoriji stvorennja ta dijaljnosti v roky Gholodomoru Vseukrajinsjkogho tovarystva «Druzi ditej») [«Friends» with a stone in his bosom (To the history of creation and activity during the Holodomor of the All-Ukrainian Society «Friends of Children»)]. Scriptorium nostrum, 1. P. 205-222. Rezhym dostupu: http://sn.kspu.edu/index.php/sn/article/view/23/24 [in Ukranian].

Uljanych, V.I. (2004). Teror gholodom i povstansjka borotjba proty ghenocydu ukrajinciv u 1923-1933 rokakh [The famine terror and the insurgent struggle against the genocide of Ukrainians in 1923-1933]. Kyjiv: DP «Ekspres-Polighraf», 82 p. [in Ukranian].

Veselova, O.M., Marochko, V.I., Movchan, O.M. (2000). Gholodomory v Ukrajini: 1921-1923, 19321933, 1946-1947: Zlochyny proty narodu [The Famines in Ukraine: 1921-1923, 1932-1933, 19461947: Crimes against the people]. 2-e vyd., dop. Kyjiv, Njju-Jork: Vyd-vo M.P. Kocj, 274 p. [in Ukranian].

Zinchenko, A.Gh. (2002). Dytjacha bezprytuljnistj v radjansjkij Ukrajini v 20-kh-pershij polovyni 30kh rokiv $X X$ stolittja: avtoreferat dysertaciji kandydata istorychnykh nauk: 07.00.01. [Child homelessness in Soviet Ukraine in the 1920s and the first half of the 1930s of the XX century: the dissertation author's abstract of the candidate of historical sciences]. Odesa, 17 p. [in Ukranian]. 